\section{Quality and Chemical Changes Associated with Flavor of 'Camarosa' Strawberries in Response to a $\mathrm{CO}_{2}$-enriched Atmosphere}

\author{
Clara Pelayo-Zaldívar ${ }^{1}$ \\ Departamento de Biotecnología, Universidad Autónoma Metropolitana- \\ Iztapalapa, C.P. 09340, D. F., México
}

Jameleddine Ben Abda

Département d'Agroalimentaire, Ecole Supérieure d'Horticulture et d'Elevage de Chott-Mariem, 4042 Sousse, Tunisia

\author{
Susan E. Ebeler \\ Department of Viticulture and Enology, University of California, One Shields \\ Avenue, Davis, CA 95616
}

Adel A. Kader

Department of Plant Sciences, University of California, One Shields Avenue, Davis, CA 95616

Additional index words. Fragaria $\times$ ananassa, aroma compounds, volatiles, fermentative metabolites

\begin{abstract}
Quality and chemical changes associated with flavor were evaluated in 'Camarosa' strawberries (Fragaria $\times$ ananassa) that had been kept at $5{ }^{\circ} \mathrm{C}$ in air or in air $+20 \mathrm{kPa} \mathrm{CO}$ for 3 and 6 days to elucidate possible factors contributing to the loss of flavor during storage. The elevated $\mathrm{CO}_{2}$ treatment did not affect flesh firmness, total soluble solids, $\mathbf{p H}$, or titratable acidity. In contrast, decreases in color (as indicated by a higher hue angle value) and in concentrations of sucrose, reducing sugars, and citric acid were detected in fruits exposed to elevated $\mathrm{CO}_{2}$. Fermentative metabolites were present in strawberries stored in air and in higher concentration in those kept in air $+20 \mathrm{kPa}$ $\mathrm{CO}_{2}$. Also, strawberries kept in air $+20 \mathrm{kPa} \mathrm{CO}$ had higher levels of ethyl esters and a major reduction in the level of methyl esters. Thus, clear differences in the aroma profile of strawberries at harvest and after 3 and 6 days of storage at $5^{\circ} \mathrm{C}$ in air or air $+20 \mathrm{kPa}$ $\mathrm{CO}_{2}$ were observed. This change in the volatile aroma profile is probably the primary factor contributing to the loss of strawberry flavor during storage.
\end{abstract}

The quality of fresh fruits can be defined in terms of factors such as appearance, firmness, color, flavor, and nutritional value. Modified atmospheres (MA) containing 10$20 \mathrm{kPa} \mathrm{CO}_{2}$ have been applied commercially for many years to reduce decay incidence and to preserve quality attributes of strawberries (Harvey, 1982). However, not all quality characteristics can be preserved to the same extent. Flavor tends to decline before changes in appearance signal the end of acceptable postharvest life (Pelayo et al., 2003).

Sugars and acids together with aroma compounds are the primary constituents determining strawberry (Fragaria $\times$ ananassa Dutch.) flavor. Strawberries stored in $\mathrm{CO}_{2}-$

Received for publication 29 May 2006. Accepted for publication 23 Oct. 2006.

Clara Pelayo is indebted to CONACYT and UAMI, Mexico, for their support during her Ph.D. studies. We thank Betty Hess-Pierce, Da-Mi Jung, and Dagoberto Castillo for their technical assistance.

${ }^{1}$ To whom correspondence should be addressed; e-mailcpel@xanum.uam.mx. enriched controlled atmospheres (CAs) (Holcroft and Kader, 1999a) and those stored in MAs (Sanz et al., 1999) had reduced increase in the levels of glucose and fructose over time. Also, decreased levels of citric and malic acids in 'Selva' strawberries stored at $5{ }^{\circ} \mathrm{C}$ in air were greater in strawberries stored in $\mathrm{CO}_{2}$-enriched atmospheres (Holcroft and Kader, 1999a). Thus, pH increases during storage were greater in $\mathrm{CO}_{2}$-stored strawberries than in those kept in air, and a corresponding change was observed in titratable acidity (TA). Similarly, Fernandez-Trujillo et al. (1999) found that malate concentrations were $22 \%$ lower in $20 \mathrm{kPa} \mathrm{CO}_{2}$ - stored than in air-stored fruit of seven strawberry cultivars, but the level of citric acid was unaffected by the $\mathrm{CO}_{2}$ treatment.

Among aroma compounds, esters are apparently the volatiles most affected by $\mathrm{CO}_{2}$-enriched atmospheres. The levels of ethyl acetate and ethyl butyrate increased over isopropyl, propyl, and butyl acetates in 'Chandler' strawberries at $5^{\circ} \mathrm{C}$ in $50 \mathrm{kPa} \mathrm{CO}_{2}$ sucrose concentration with a concomitant enriched atmospheres (Ke et al., 1994). The authors hypothesized that, under these conditions, the synthesis of ethyl esters predominates over other alkyl esters and the synthesis of other acyl esters predominates over acetates. Larsen and Watkins (1995a) reported an increase in ethyl butyrate and ethyl hexanoate in 'Pajaro' strawberries stored at $0{ }^{\circ} \mathrm{C}$ in $20 \mathrm{kPa} \mathrm{CO}$. Watkins et al. (1999) found that the increase in acetaldehyde, ethanol, and ethyl acetate in strawberries stored at $2{ }^{\circ} \mathrm{C}$ in $20 \mathrm{kPa} \mathrm{CO}_{2}$ was cultivar dependent. However, no information is available about the effect of CA on branched esters, which apparently are important contributors to the aroma of strawberries (Schieberle and Hofmann, 1997).

In addition to flavor components, $\mathrm{CO}_{2}$ enriched atmospheres slow the softening rate of strawberries (Kader, 1986; Ke et al., 1991) or increase the fruit flesh firmness (Harker et al., 2000). Strawberries stored in $\mathrm{CO}_{2}$ enriched atmospheres were lighter and less red than air-stored fruit (Gil et al., 1997; Holcroft and Kader, 1999b; Watkins et al., 1999). Strawberries contain 580 to 2100 $\mathrm{mg} \cdot \mathrm{kg}^{-1}$ of total phenolic compounds (Kader, 1991), and these compounds play a role in the astringency perception of strawberries (Perkins-Veazie, 1995). The total content of phenolic compounds increased with time in storage at $5^{\circ} \mathrm{C}$ but was unaffected by storage atmosphere (in air or in air $+10-20 \mathrm{kPa} \mathrm{CO}_{2}$ ) in 'Selva' strawberries (Holcroft and Kader, 1999b).

The objectives of the present work were to evaluate changes of the primary flavor components of 'Camarosa' strawberries in response to a $20 \mathrm{kPa} \mathrm{CO}_{2}$-enriched atmospheres and to elucidate the possible factors contributing to the loss of flavor during storage.

\section{Materials and Methods}

Experimental procedure. Strawberries (Fragaria ×ananassa Dutch. cv. Camarosa) were harvested in ripe condition (red color on more than $95 \%$ of the surface) from Watsonville, Calif., transported to the University of California, Davis, on the same day, and stored at $0{ }^{\circ} \mathrm{C}$ until the following morning. The strawberries were sorted to eliminate damaged, overripe, and poor-quality fruit and to obtain samples of uniform color. Twenty-five fruits were selected randomly and placed in a $10-\mathrm{L}$ jar as one replicate. Three replicates were used per treatment. The jars were stored at $5{ }^{\circ} \mathrm{C}$ and ventilated with a continuous humidified flow of either air or air enriched with $20 \mathrm{kPaCO}_{2}$, at a rate of 150 $\mathrm{mL} \cdot \mathrm{min}^{-1}$ using flow boards and capillary tubing as flow meters. The composition of the atmosphere was verified daily with an IR gas analyzer (Horiba 2000R; Horiba Instruments, Irvine, Calif.) and maintained within $\pm 10 \%$ of the required partial pressure. The RH was $95 \%$ to $100 \%$, and the fruit weight loss was less than $1 \%$ in every jar. Three 20-berry samples at harvest and 20 fruits from each jar after 3 and $6 \mathrm{~d}$ of storage at $5{ }^{\circ} \mathrm{C}$ were randomly selected and analyzed for color 
and firmness. Same fruits were then cut in small pieces, wrapped in cheesecloth, and squeezed with a hand press, and the clear juice used for analysis. Total soluble solids (TSS), $\mathrm{pH}$, and TA were determined using standard procedures and fermentative metabolites and aroma compounds by the analytical methods described below. In addition, three five-berry samples at harvest and five fruits from every jar, randomly selected, were directly frozen in liquid nitrogen and stored at $-25{ }^{\circ} \mathrm{C}$ for subsequent analysis of sugars, organic acids, and phenolics.

Sugars, organic acids, and phenolics. Frozen strawberries were thawed and homogenized in a blender. From the homogenate, three samples of $10 \mathrm{~g}$ were used for the analysis of sugars and organic acids, and $10 \mathrm{~g}$ for phenolic quantification. Glucose, fructose, sucrose, and citric and malic acids were analyzed according to Pérez et al. (1997) with HPLC (Hewlett-Packard, Palo Alto, Calif.) using a photodiode array detector (DAD model 1040 M) (Hewlett-Packard) in series with a refractive index detector. Organic acids were detected at $210 \mathrm{~nm}$, and sugars were identified by the retention times of the reference compounds and quantified by standard curves. Phenolics were analyzed by using the Folin-Ciocalteu spectrophotometric method (Singleton and Rossi, 1965). The quantification was based on a $p$-coumaric acid standard curve. Results are reported on a fresh weight basis.

Fermentative metabolites. Samples of $5 \mathrm{~mL}$ of fresh strawberry juice were placed in crimp-seal $10-\mathrm{mL}$ vials containing $2 \mathrm{~g}$ of $\mathrm{NaCl}$, sealed and frozen at $-25{ }^{\circ} \mathrm{C}$ until the analysis of acetaldehyde, ethanol, and ethyl acetate was conducted. The frozen samples were thawed, and the vials were incubated at $30{ }^{\circ} \mathrm{C}$ for $15 \mathrm{~min}$. After $10 \mathrm{~s}$ of agitation, a sample of $1 \mathrm{~mL}$ was withdrawn from the headspace and injected into a HP 5890 GC equipped with a flame ionization detector (FID) and analyzed using a 60/80 Carbopack $\mathrm{B} / 5 \%$ Carbowax $20 \mathrm{M}, 1.8 \mathrm{~m} \times 2 \mathrm{~mm}$ ID column (Supelco, Bellefonte, Pa.). Injector and detector temperatures were 115 and $200{ }^{\circ} \mathrm{C}$, respectively, and the oven temperature started at $80^{\circ} \mathrm{C}$, increased to $130{ }^{\circ} \mathrm{C}$ at $10{ }^{\circ} \mathrm{C} / \mathrm{min}$ and held for $6 \mathrm{~min}$. Fermentative metabolites were identified by the retention times of reference compounds and concentrations calculated by using standard aqueous solutions of every analyte and by preparing the corresponding standard curves under the same conditions as those used for the strawberry samples.

Aroma compounds. Fresh strawberry juice was immediately frozen in liquid $\mathrm{N}_{2}$ and kept at $-25{ }^{\circ} \mathrm{C}$ until volatiles were analyzed. After 10-20 min, the frozen samples were at room temperature, a $\mathrm{NaOH}+$ sodium salt of the ethylenediaminetetracetic acid (EDTA) solution was added to the juice to obtain a final $\mathrm{pH}$ of $6.2-6.5$ and a $50 \mathrm{~mm}$ concentration of the chelating agent $(\approx 10 \%$ of the juice volume). EDTA was added to limit enzymatic and chemical reactions and therefore to prevent the generation of aroma artifacts. At a pH of 6-7, EDTA sequesters important cations acting as cofactors of enzymes and catalyzers of oxidative reactions. Five-milliliter samples of this juice were placed in a crimp-sealed $16-\mathrm{mL}$ vial containing $2 \mathrm{~g}$ of $\mathrm{NaCl}$ to facilitate the release of aroma compounds, sealed with a black Viton septum and 20-mm crimp caps, agitated for $30 \mathrm{~s}$, and analyzed by a headspacesolid phase micro-extraction technique (SPME) using an HP 5890 GC apparatus (Hewlett Packard) coupled to a mass spectrometer (MS) (HP 5971 with an electronic upgrade to a model 5972) and a Varian 8200 cx autosampler (Varian, Walnut Creek, Calif). A $60 \mathrm{~m} \times 0.32 \mathrm{~mm}$ ID, $1 \mu \mathrm{m}$ film thickness DB-WAXETR capillary column (J \& W Scientific, Folsom, Calif.) and a temperature program $\left(50{ }^{\circ} \mathrm{C}\right.$ for $1 \mathrm{~min}$. increased to $110{ }^{\circ} \mathrm{C}$ at $5{ }^{\circ} \mathrm{C} / \mathrm{min}$, then to $180{ }^{\circ} \mathrm{C}$ at $20{ }^{\circ} \mathrm{C} / \mathrm{min}$, and held for $10 \mathrm{~min}$ ) were used to separate the analytes. Injector and detector temperatures were 200 and $280{ }^{\circ} \mathrm{C}$, respectively. The autosampler was fitted with a $65 \mu \mathrm{m}$ Carbowax divinyl benzene SPME fiber (Supelco) and programmed for an 11-min cycle: 10-min adsorption time for sampling the headspace and $1 \mathrm{~min}$ for desorption in the $\mathrm{GC}$ injector. The headspace samplings were done at $25-30{ }^{\circ} \mathrm{C}$. The identification of aroma compounds was initially accomplished by matching mass spectra with library values. Identities of the major volatiles were confirmed by injecting standard aqueous solutions of each compound directly into the GC-MS and also by trapping the volatiles from the headspace by the SPME fiber under the same condition as those used for the strawberry juice samples. Quantification was carried out by comparing peak areas of analyte to that of 2,6-dimethyl-5-heptenal added at $280 \mathrm{~nL} \cdot \mathrm{L}^{-1}$ as the internal standard to the strawberry samples (Ulrich et al., 1995).

Statistical analysis. SAS (version 7.0, SAS Institute, Cary, N.C.) was used to perform analysis of variance (ANOVA) and to obtain LSD $(5 \%)$ values of each of the main effects. Data presented are the means of three replicates.

\section{Results and Discussion}

Quality attributes. Lightness and chroma in 'Camarosa' strawberries decreased after $6 \mathrm{~d}$ in air storage as has been previously reported for other cultivars (Gil et al., 1997; Holcroft and Kader, 1999b; Pérez et al., 1996; Watkins et al., 1999). However, in contrast with these reports an increase in hue value was observed in the air stored 'Camarosa' fruits (Table 1). Because anthocyanins continue to be synthesized in strawberries kept at $5{ }^{\circ} \mathrm{C}$ in air (Holcroft and Kader, 1999b; Perkins-Veazie, 1995), this unexpected increase in the $h$ value could be attributed to the fruit being picked in a more advanced stage of ripeness. The only color variable that was significantly different between elevated $\mathrm{CO}_{2}$ - and air-stored fruit was hue value after $6 \mathrm{~d}$. In agreement with previous reports (Gil et al., 1997; Holcroft and Kader, 1999b), the hue value of straw- berries kept in $\mathrm{CO}_{2}$-enriched atmospheres was higher, and consequently the fruits were orange red compared with those stored in air for $6 \mathrm{~d}$ at $5^{\circ} \mathrm{C}$, which were red.

Firmness increased with storage time, but was unaffected by the elevated $\mathrm{CO}_{2}$-atmosphere (Table 1). Low temperature increases the flesh firmness of strawberries (Larsen and Watkins, 1995b; Watkins et al., 1999), and an increase in fruit firmness by high levels of $\mathrm{CO}_{2}$ has been reported (Goto et al., 1996; Larsen and Watkins, 1995a; Smith and Skog, 1992; Ueda and Bai, 1993). The degree of increase in flesh firmness depended on cultivar and days in storage (Watkins et al., 1999). Lack of effect of $\mathrm{CO}_{2}$ on firmness of 'Camarosa' strawberries may be due to cultivar differences or the use of riper fruit than in other studies.

Reduced TSS was observed with time in both air- and $\mathrm{CO}_{2}$-stored strawberries, but there was no clear difference between the two storage treatments (Table 1). Similarly, the concentration of sucrose decreased during storage and to a greater extent after $6 \mathrm{~d}$ under $\mathrm{CO}_{2}$ enrichment (Table 2). Sucrose is hydrolyzed during ripening (Woodward, 1972), and this hydrolysis continues during storage (Holcroft and Kader, 1999a; Pelayo et al., 2003). Sucrose decreased by $35 \%$ in air- and by $56 \%$ in air $+\mathrm{CO}_{2}$-stored fruits after $6 \mathrm{~d}$ at $5{ }^{\circ} \mathrm{C}$. Also, a clear decrease on the level of glucose, fructose and total sugars was observed by the effect of air $+20 \mathrm{kPa} \mathrm{CO}_{2}$ after $6 \mathrm{~d}$. Thus, sugars were more actively metabolized in $\mathrm{CO}_{2}$ - than in air-stored strawberries. Under stress conditions, such as those imposed by high levels of $\mathrm{CO}_{2}$, the rate of glycolysis increases and it has been hypothesized that this change may be mediated by the regulatory metabolite fructose 2,6biphosphate (Purvis, 1997). The level of this compound regulates the adaptive pathway of glycolysis and its concentration changes with environmental perturbations. With respect to the proportion of individual sugars, it remained essentially the same in strawberries stored in either air or air $+20 \mathrm{kPa} \mathrm{CO}_{2}$ (sucrose $4 \%$ to $7 \%$, glucose $41 \%$ to $44 \%$, and fructose $52 \%$ to $53 \%$ ).

Fruits under elevated $\mathrm{CO}_{2}$ did not show changes in TA or $\mathrm{pH}$ (Table 1) but they had higher losses of citric and total organic acids than strawberries stored in air after $6 \mathrm{~d}$ of storage (Table 2). Holcroft and Kader (1999a) reported a greater increase in $\mathrm{pH}$ with parallel decreases in TA and in the level of organic acids in 'Selva' strawberries stored at $5{ }^{\circ} \mathrm{C}$ in 10 or $20 \mathrm{kPa} \mathrm{CO}$ than in those stored in air. It appears that smaller changes in juice acidity took place in 'Camarosa' strawberries harvested in a more ripe condition. Thus, changes in $\mathrm{pH}$ and $\mathrm{TA}$ were not observed over time, and the reduction in the level of citric acid, the dominant organic acid in strawberries, was small.

An increase in the concentration of total phenolic compounds from 1850 to 2120 $\mathrm{mg} \cdot \mathrm{kg}^{-1}$ was observed after $6 \mathrm{~d}$ of storage in air-stored but not in $\mathrm{CO}_{2}$-stored fruits $(1850$ $\left.1945 \mathrm{mg} \cdot \mathrm{kg}^{-1}\right)$. Similarly, Holcroft and Kader 
Table 1. $\mathrm{L}^{*}, \mathrm{C}^{*}$, and hue angle color measurements, $\mathrm{pH}$, titratable acidity, total soluble solids and firmness of 'Camarosa' strawberries at harvest and after storage for 3 and 6 days in air or air $+20 \mathrm{kPa} \mathrm{CO}$ at $5{ }^{\circ} \mathrm{C}$ (means $\pm \mathrm{sD}$ ).

\begin{tabular}{|c|c|c|c|c|c|c|c|c|}
\hline \multicolumn{2}{|c|}{ Storage } & \multicolumn{3}{|c|}{ Color } & \multirow[b]{2}{*}{ Firmness $(\mathrm{N})$} & \multirow[b]{2}{*}{ TSS (\%) } & \multirow[b]{2}{*}{$\mathrm{pH}$} & \multirow[b]{2}{*}{ TA (\%) } \\
\hline Days & Atmosphere & $\mathrm{L}^{*}$ & $\mathrm{C}^{*}$ & $\overline{\mathrm{H} \text { (degrees) }}$ & & & & \\
\hline 3 & Air & $32.5 \pm 0.4$ & $38.8 \pm 0.5$ & $25.6 \pm 0.2$ & $3.3 \pm 0.2$ & $9.2 \pm 0.3$ & $3.67 \pm 0.03$ & $0.91 \pm 0.02$ \\
\hline 6 & $\mathrm{Air}+20 \mathrm{kPa} \mathrm{CO} 2$ & $34.1 \pm 0.9$ & $36.2 \pm 1.0$ & $30.5 \pm 1.1$ & $3.8 \pm 0.1$ & $8.5 \pm 0.1$ & $3.67 \pm 0.06$ & $0.93 \pm 0.04$ \\
\hline \multicolumn{9}{|l|}{$\operatorname{LSD}(5 \%)$} \\
\hline Atmosphere & & 1.4 & 1.1 & 2.0 & 0.3 & 0.20 & 0.09 & 0.06 \\
\hline
\end{tabular}

Table 2. Sugars and organic acids of 'Camarosa' strawberries at harvest and after 3 and $6 \mathrm{~d}$ of storage at $5{ }^{\circ} \mathrm{C}$ in air or air $+20 \mathrm{kPa} \mathrm{CO} 2(\mathrm{means} \pm \mathrm{SD})$.

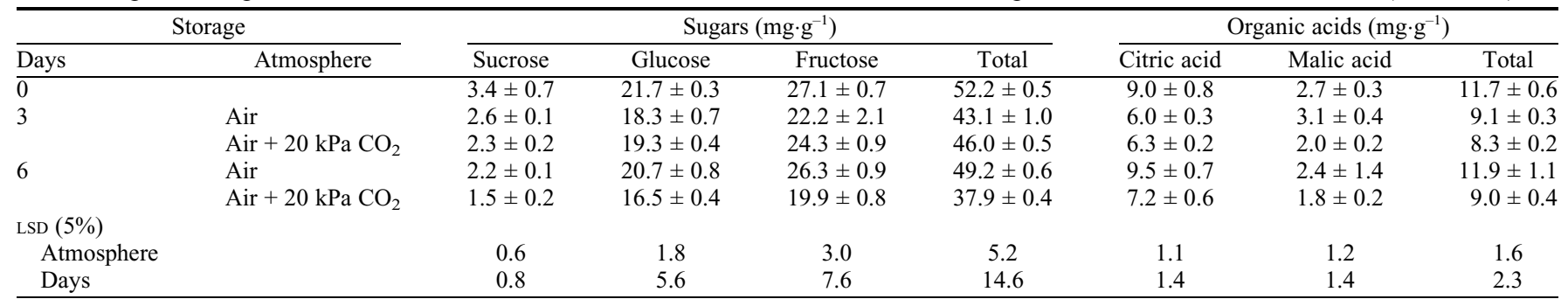

(1999b) found in 'Selva' strawberries that the level of these compounds increased with time at $5{ }^{\circ} \mathrm{C}$, but it was unaffected by 10 or $20 \mathrm{kPa}$ $\mathrm{CO}_{2}$-enriched atmospheres. However, in the same work the authors found that concentrations of some individual phenolic compounds were usually lower in the $\mathrm{CO}_{2}$ than in the air-stored fruits, suggesting that the rate of phenolic degradation may increase in strawberries subjected to elevated $\mathrm{CO}_{2}$ atmospheres after $10 \mathrm{~d}$ of storage. The mechanism by which $\mathrm{CO}_{2}$ interacts with phenolic compounds is not clearly understood. It is known that acetaldehyde, a fermentative metabolite that can accumulate during exposure to high levels of $\mathrm{CO}_{2}$, binds phenolic compounds such as tannins and promotes their polymerization (Es-Safi et al., 1999; Pesis and Ben-Arie, 1986).

Fermentative metabolites. Ethyl acetate was the only fermentative metabolite detected in freshly harvested strawberries (Fig. 1A), but during storage acetaldehyde and ethanol were also detected in both airand air $+\mathrm{CO}_{2}$-stored fruits. The concentration of these compounds increased dramatically with time and storage atmosphere, dominating the aroma profiles of 'Camarosa' strawberries during storage (Fig. 2). After only $3 \mathrm{~d}$ at $5{ }^{\circ} \mathrm{C}$, they represented $57 \%$ and $63 \%$ of the total volatiles quantified in the airand $\mathrm{CO}_{2}$ stored fruit, respectively. Some symptoms of over-ripeness such as calyx dehydration and external tissue breakdown were detected in fruit stored in air, but not in those kept under air $+20 \mathrm{kPa} \mathrm{CO}_{2}$. Thus, the accumulation of these volatiles seemed to be an indicator of overipeness in the air-stored fruit and a manifestation of physiological stress in the $\mathrm{CO}_{2}$-stored fruit. Our results indicate that 'Camarosa' strawberries belong to the category of cultivars accumulating

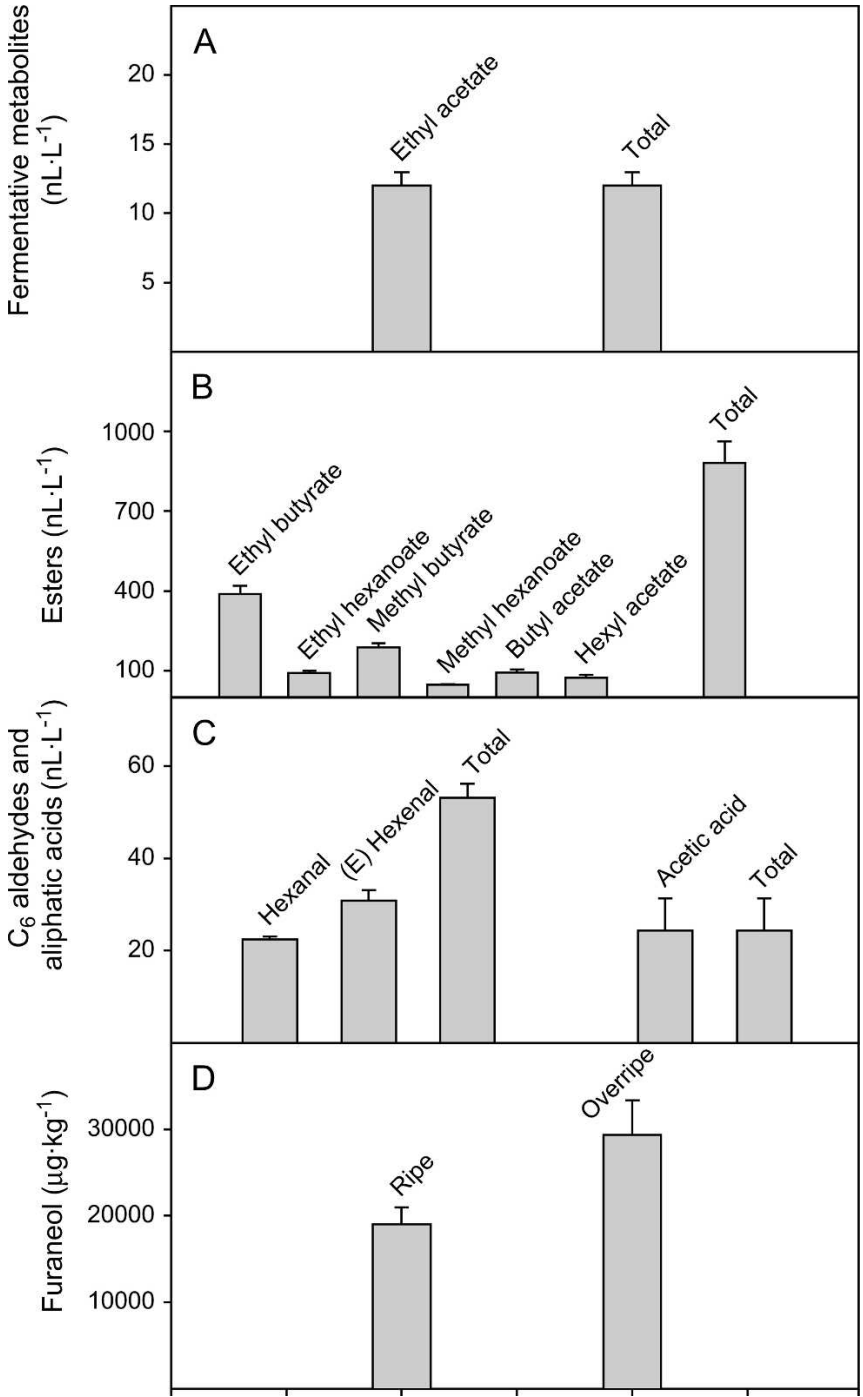

Fig. 1. Aroma composition of 'Camarosa' strawberries harvested in ripe condition, except for furaneol for which overripe fruits were also analyzed (means $\pm \mathrm{SD}$ ). 

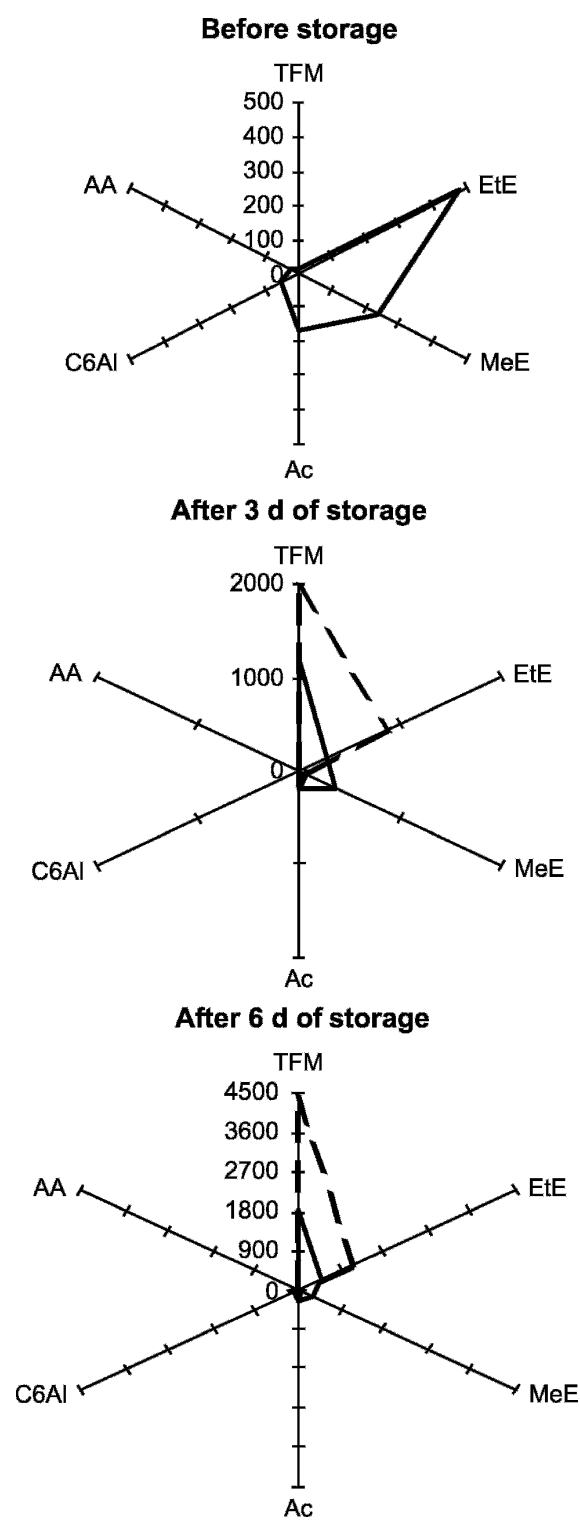

Fig. 2. Aroma profiles of 'Camarosa' strawberries before storage and after 3 and $6 \mathrm{~d}$ at $5{ }^{\circ} \mathrm{C}$ in air (continuous line) or air $+20 \mathrm{kPa} \mathrm{CO}_{2}$ (dotted line) (means $\pm \mathrm{SD}$ ) (TFM, total fermentative metabolites; EtE, ethyl esters; MeE, methyl esters; Ac, acetates; $\mathrm{C}_{6} \mathrm{Al}, \mathrm{C}_{6}$ aldehydes; AA, acetic acid, in $\mathrm{nL} \cdot \mathrm{L}^{-1}$ ).

fermentative metabolites in response to elevated $\mathrm{CO}_{2}$ (Watkins et al., 1999).

Aroma compounds. The most abundant aroma compounds present in ripe 'Camarosa' strawberries were esters and furaneol. Esters comprised $91 \%$ of the total aroma compounds $\left(971 \mathrm{~nL} \cdot \mathrm{L}^{-1}\right)$ quantified by GC-MS, followed by $\mathrm{C}_{6}$ aldehydes $(5 \%)$ and acetic acid (3\%) (Fig. 1B and C). Furaneol, which was quantified by HPLC because of its thermoinstability, was present at 19,000 $\mu \mathrm{g} \cdot \mathrm{kg}^{-1}$ in fruit harvested ripe and at 29,000 $\mu \mathrm{g} \cdot \mathrm{kg}^{-1}$ in fruit harvested in an overripe condition (Fig. 1D). These data confirm previous reports indicating that the synthesis of furaneol, and other furanones, continues after strawberries have attained full ripeness on the plant (Pérez et al., 1996).

Table 3. Levels (nM) of alkyl and acyl fractions required to synthesize the observed amount of esters in 'Camarosa' strawberries stored at $5{ }^{\circ} \mathrm{C}$ in air or air $+20 \mathrm{kPa} \mathrm{CO}_{2}$.

\begin{tabular}{|c|c|c|c|c|c|c|c|c|}
\hline \multicolumn{2}{|r|}{ Storage } & \multicolumn{5}{|c|}{ Alkyl and acyl straight chain fractions (nM) } & \multicolumn{2}{|c|}{$\begin{array}{c}\text { Acyl branched } \\
\text { chain fractions (nM) }\end{array}$} \\
\hline Days & Atmosphere & $\begin{array}{c}\mathrm{C}_{1} \\
\text { (methyl) }\end{array}$ & $\begin{array}{c}\mathrm{C}_{2} \\
\text { (ethyl) }\end{array}$ & $\begin{array}{c}\mathrm{C}_{2} \\
\text { (acetate) }\end{array}$ & $\begin{array}{c}\mathrm{C}_{4} \\
\text { (butyl, } \\
\text { butyrate) }\end{array}$ & $\begin{array}{c}\mathrm{C}_{6} \\
\text { (hexyl, } \\
\text { hexanoate) }\end{array}$ & $\begin{array}{c}\mathrm{C}_{4} \\
\text { (methyl-2 } \\
\text { propanoate) }\end{array}$ & $\begin{array}{c}\mathrm{C}_{5} \\
\text { (methyl-2- } \\
\text { butyrate) }\end{array}$ \\
\hline 0 & & 2.0 & 3.5 & 1.1 & 5.3 & 1.3 & 0 & 0 \\
\hline \multirow[t]{2}{*}{3} & Air & 2.9 & 1.9 & 1.3 & 4.7 & 1.5 & 0 & 0 \\
\hline & $\mathrm{Air}+20 \mathrm{kPa} \mathrm{CO} 2$ & 0.6 & 6.1 & 1.0 & 4.7 & 2.6 & 0.1 & 0.3 \\
\hline \multirow[t]{2}{*}{6} & Air & 2.5 & 3.5 & 1.8 & 5.5 & 2.4 & 0.0 & 0.07 \\
\hline & Air $+20 \mathrm{kPa} \mathrm{CO} 2$ & 0.2 & 7.9 & 0.9 & 5.5 & 2.7 & 0.2 & 0.6 \\
\hline
\end{tabular}

Ethyl esters, which were already abundant in strawberries at the beginning of storage (Fig. 1B), were also present in air-stored fruits after 3 and $6 \mathrm{~d}$, but a remarkable increase in the level of these compounds was observed in the strawberries stored under air $+20 \mathrm{kPa} \mathrm{CO}$ (Fig. 2). Levels of methyl esters and butyl and hexyl acetates tended to increase in air-stored fruit (from 236 and 166 to 314 and $264 \mathrm{~nL} \cdot \mathrm{L}^{-1}$, respectively, after $6 \mathrm{~d}$ of storage), but to decrease in strawberries stored under air $+20 \mathrm{kPa} \mathrm{CO}_{2}$ (28 and $132 \mathrm{~nL} \cdot \mathrm{L}^{-1}$, respectively, after $6 \mathrm{~d}$ of storage). These results support the findings of Ke et al. (1994), who reported the predominant synthesis of ethyl esters over methyl esters in $\mathrm{CO}_{2}$-stored fruit, as well as the reduction in the level of acetates. Notably, the branched esters, ethyl 2-methyl propanoate and ethyl 2methyl butyrate, considered important aroma compounds of strawberries (Schieberle, 1994; Schieberle and Hofmann, 1997), were not present before storage. In air-stored fruits, only ethyl 2-methyl butyrate was detected in trace amounts while both ethyl 2-methyl propanoate and ethyl 2-methyl butyrate were present in the air $+\mathrm{CO}_{2}$-stored fruits in more than trace amounts (32 and $88 \mathrm{~nL} \cdot \mathrm{L}^{-1}$, respectively, after $6 \mathrm{~d}$ of storage). Because valine and isoleucine are precursors of these branched esters (Drawert, 1975; Lindsay, 1996; Tressl et al., 1975), their presence may be an indication of enhanced protein degradation in the overripe, air-stored fruits and in those subjected to the physiological stress incited by elevated $\mathrm{CO}_{2}$.

The concentration of total aroma compounds increased throughout the storage period in air and to a greater extent in $\mathrm{CO}_{2}$ stored fruit mainly due to the enhanced production of fermentative metabolites and ethyl esters (Fig. 2).

In the end, although quantification of aroma compounds with SPME using only one internal standard is not very accurate, in this study, that method was able to show differences between treatments for many peaks.

To analyze the contribution of metabolic pathways to the synthesis of esters other than ethyl acetate during the storage of 'Camarosa' fruit, the average concentration of the three replicates of esters (in $\mathrm{nL} \cdot \mathrm{L}^{-1}$ ) of each sample were converted into nanomoles. Considering that every ester molecule comes from an alcohol molecule (alkyl fraction) and an aliphatic acid molecule (acyl fraction), the number of nanomoles of alkyl and acyl fractions required to synthesize the observed amount of every ester was calculated. Finally, fractions of the same carbon number coming from the same metabolic pathway were added (Table 3 ).

The amount of methanol, an alcohol coming from the hydrolysis of pectins, used for the synthesis of methyl esters increased in air and decreased in air $+\mathrm{CO}_{2}$-stored fruit (Table 3 ). However, the concentration of this alcohol, measured by GC in the juice of strawberries (data not shown), remained the same throughout the $6 \mathrm{~d}$ in both storage atmospheres. Thus, apparently it was not the availability of methanol, but the higher levels of ethanol present in the $\mathrm{CO}_{2}$-stressed fruit, that resulted in the preferential synthesis of ethyl esters over methyl esters in the $\mathrm{CO}_{2}$-stored fruit.

The nanomoles of fractions $\mathrm{C}_{4}$ (butyl and butyrate), reported to come from $\beta$-oxidation and synthesis of fatty acids (Sanz et al., 1997), were the same in strawberries kept under both storage atmospheres. However, the $\mathrm{C}_{6}$ fractions (hexyl and hexanoate) increased after $6 \mathrm{~d}$ in air and to a higher level after 3 and $6 \mathrm{~d}$ in air $+20 \mathrm{kPa} \mathrm{CO}$. Because $\mathrm{C}_{6}$ fractions can be generated by both $\beta$-oxidation and the lipoxygenase (LOX) pathways, the observed increase in $\mathrm{C}_{6}$ fractions may be due to an alteration of LOX activity by over-ripeness and by the exposure of the fruit to elevated $\mathrm{CO}_{2}$.

Finally, the nanomoles of $\mathrm{C}_{4}$ and $\mathrm{C}_{5}$ acyl branched chains indicated a greater contribution of the amino acids valine and isoleucine, respectively, to the synthesis of esters in $\mathrm{CO}_{2}$ - than in air-stored fruits.

\section{Conclusions}

The accumulation of fermentative metabolites in both air- and air $+20 \mathrm{kPa} \mathrm{CO}_{2}$-stored 'Camarosa' strawberries and the shift in the synthesis of methyl to ethyl esters in fruit exposed to air $+20 \mathrm{kPa} \mathrm{CO}_{2}$ created a new profile of aroma compounds that may affect fruit aroma perception. This change in the volatile aroma profile is probably the primary factor contributing to the loss of strawberry flavor during storage. Simultaneous changes in other nonvolatile flavor components, including sugars and citric acid, may also contribute to the loss of strawberry flavor during storage. Additionally, changes in phenolic compounds and the increase in firmness by the effect of low temperature may have an 
influence on the release of volatiles and therefore, on the flavor perception of strawberries. Sensory evaluation is required to confirm these results.

\section{Literature Cited}

Drawert, F. 1975. Biochemical formation of aroma compounds, p. 13-39. In: H. Maarse and P.J. Groenen (eds.). Aroma research. Proc. Int. Symp. Aroma Res. Zeist, The Netherlands.

Es-Safi, N.-E., H. Fulcrand, V. Cheynier, and M. Moutounet. 1999. Competition between $(+)$-catechin and (-)-epicatechin in acetaldehyde-induced polymerization of flavanols. J. Agr. Food Chem. 47:2088-2095.

Fernandez-Trujillo, J.P., J.F. Nock, and C.B. Watkins. 1999. Fermentative metabolism and organic acid concentrations in fruit of selected strawberry cultivars with different tolerance to carbon dioxide. J. Amer. Soc. Hort. Sci. 124:696-701.

Gil, M.I., D.M. Holcroft, and A.A. Kader. 1997. Changes in strawberry anthocyanins and other polyphenols in response to carbon dioxide treatments. J. Agr. Food Chem. 45:1662-1667.

Goto, T., M. Goto, K. Chachin, and T. Iwata. 1996. The mechanism of the increase of firmness in strawberry fruit treated with $100 \% \mathrm{CO}_{2}$. Nippon Shokuhin Kagahu Kaishi 43:1158-1162.

Harker, F.R., H.J. Elgar, C.B. Watkins, P.J. Jackson, and I.C. Hallett. 2000. Physical and mechanical changes in strawberry fruit after high carbon dioxide treatments. Postharv. Biol. Technol. 19:139-146.

Harvey, J.M. 1982. CO2 atmospheres for truck shipments of strawberries, p. 359-365. In: D.G. Richardson and M. Meheriuk (eds.) Controlled atmospheres for storage and transport of perishable agricultural commodities. Timber Press, Portland, Ore.

Holcroft, D.M. and A.A. Kader. 1999a. Carbon dioxide-induced changes in $\mathrm{pH}$ and organic acid metabolism may affect color of stored strawberry fruit. Postharvest Biol. Technol. 17:19-32.

Holcroft, D.M. and A.A. Kader. 1999b. Carbon dioxide-induced changes in color and anthocyanin synthesis of stored strawberry fruits. HortScience 34:1244-1248.
Kader, A.A. 1986. Biochemical and physiological bases for effects of controlled and modified atmospheres on fruits and vegetables. Food Technol. 40(5):99-100 and 102-104.

Kader, A.A. 1991. Quality and its maintenance in relation to the postharvest physiology of strawberry, p. 145-152. In: A. Dale and J.J. Luby (eds.). The strawberry into the 21 st century. Timber Press, Portland, Ore.

Ke, D., L. Goldstein, M. O'Mahony, and A.A Kader. 1991. Effects of short-term exposure to low $\mathrm{O}_{2}$ and high $\mathrm{CO}_{2}$ atmospheres on quality attributes of strawberries. J. Food Sci. 56:50-54.

Ke, D., L. Zhou, and A.A. Kader. 1994. Mode of oxygen and carbon dioxide action on strawberry ester biosynthesis. J. Amer. Soc. Hort. Sci. 119:971-975.

Larsen, M. and C.B. Watkins. 1995a. Firmness and aroma composition of strawberries following short-term high carbon dioxide treatments. HortScience 30:303-305.

Larsen, M. and C.B. Watkins. 1995b. Firmness and concentration of acetaldehyde, ethyl acetate and ethanol in strawberries stored in controlled and modified atmospheres. Postharvest Biol. Technol. 5:39-50.

Lindsay, R.C. 1996. Flavors, p. 723-765. In: O.R Fennema (ed.). Food chemistry. Marcel Dekker, New York.

Pelayo, C., S.E. Ebeler, and A.A. Kader. 2003. Postharvest life and flavor quality of three strawberry cultivars kept at $5{ }^{\circ} \mathrm{C}$ in air or air $+20 \mathrm{kPa}$ $\mathrm{CO}_{2}$. Postharv. Biol. Technol. 27:171-183.

Pérez, A.G., R. Olías, C. Sanz, and J.M. Olías. 1996. Furanones in strawberries: evolution during ripening and postharvest life. J. Agr. Food Chem. 44:3620-3624

Pérez, A.G., R. Olías, J. Espada, J.M. Olías, and C. Sanz. 1997. Rapid determination of sugars, non-volatiles acids and ascorbic acid in strawberry and other fruits. J. Agr. Food Chem. 45:3545-3549.

Perkins-Veazie, P. 1995. Growth and ripening of strawberry fruit. Hort. Rev. (Amer. Soc. Hort. Sci.) 17:267-297.

Pesis, E. and R. Ben-Arie. 1986. Carbon dioxide assimilation during postharvest removal of astringency from persimmon fruit. Physiol. Plant. 67:644-648.
Purvis, A.C. 1997. The role of adaptive enzymes in carbohydrate oxidation by stressed and senescing plant tissues. HortScience 32:11651168.

Sanz, C., J.M. Olías, and A.G. Pérez. 1997. Aroma biochemistry of fruits and vegetables, p. 125155. In: F.A. Tomás-Barberán and R.J. Robins (eds.). Phytochemistry of fruits and vegetables. Clarendon Press, Oxford, U.K.

Sanz, C., A.G. Pérez, and J.M. Olías. 1999. Quality of strawberries packed with perforated polypropylene. J. Food Sci. 64:748-752.

Singleton, V.L. and J.A. Rossi. 1965. Colorimetry of total phenolics with phosphomolybdicphosphotungstic acid reagents. Amer. J. Enol. Viticult. 16:144-157.

Schieberle, P. 1994. Heat-induced changes in the most odour-active volatiles of strawberries, p. 354-351. In: H. Maarse and D.J. Van der Heij (eds.). Trends in flavor research. Elsevier, Amsterdam, The Netherlands.

Schieberle, P. and T. Hofmann. 1997. Evaluation of the character impact odorants in fresh strawberry juice by quantitative measurements and sensory studies on model mixtures. J. Agr. Food Chem. 45:227-232.

Smith, R.B. and L.J. Skog. 1992. Postharvest carbon dioxide treatment enhances firmness of several cultivars of strawberry. HortScience 27:420-421.

Tressl, R., M. Holzer, and M. Apetz. 1975. Biogenesis of volatiles in fruits and vegetables, p. 13-39. In: H. Maarse and P.J. Groenen (eds.). Aroma research. Proc. Int. Symp. Aroma Res.. Zeist, The Netherlands.

Ueda, Y. and J. Bai. 1993. Effect of short term exposure of elevated $\mathrm{CO}_{2}$ on flesh firmness and ester production of strawberries. J. Jpn. Soc. Hort. Sci. 62:457-464.

Ulrich, D., S. Eunert, E. Hoberg, and A. Rapp. 1995. Analyse des Erdbeeraromas mittels Festphasen-mikroextraktion. Deut. Lebensm. Rundsch. 91:349-351.

Watkins, C.B., J.E. Manzano-Mendez, J.F. Nock, J. Zhang, and K.E. Maloney. 1999. Cultivar variation in response of strawberry fruit to high carbon dioxide treatments. J. Sci. Food Agr. 79:886-890.

Woodward, J.R. 1972. Physical and chemical changes in developing strawberry fruits. J. Sci. Food Agr. 23:465-473. 